\title{
RELT wt Allele
}

National Cancer Institute

\section{Source}

National Cancer Institute. RELT wt Allele. NCI Thesaurus. Code C159402.

Human RELT wild-type allele is located in the vicinity of $11 \mathrm{q} 13.2$ and is approximately 21

$\mathrm{kb}$ in length. This allele, which encodes tumor necrosis factor receptor superfamily

member $19 \mathrm{~L}$ protein, may play a role in apoptotic signaling pathways. 